Whatever Happened to Socialization? (Forthcoming in Annual Review of Sociology)

By Jeffrey Guhin, Jessica Calarco, and Cynthia Miller-Idriss

\title{
Whatever Happened to Socialization?
}

\section{Abstract:}

Socialization is a key mechanism of social reproduction. Yet, like the functionalists who introduced the concept, socialization has fallen out of favor, critiqued for ignoring power and agency, for its teleology and incoherence, and for a misguided link to "culture of poverty" arguments. In this review, we argue for a renewed, post-functionalist use of socialization. We review the concept's history, its high point under Parsons, the reasons for its demise, its continued use in some subfields (e.g., gender, race and ethnicity, education), and alternative concepts used to explain social reproduction. We then suggest that something is lost when "socialization" is avoided or isolated in particular subfields. Without socialization, conceptions of social reproduction face problems of history, power, and transferability. We close by outlining a post-functionalist agenda for socialization research, providing a framework for of a new theory of socialization, one that builds off of cognitive science, pragmatism, the study of language, the re-interrogation of values, and the development of ideology in political socialization. 
Whatever Happened to Socialization? (Forthcoming in Annual Review of Sociology)

By Jeffrey Guhin, Jessica Calarco, and Cynthia Miller-Idriss

\section{Whatever Happened to Socialization?}

The study of social reproduction is central to sociology, driven by one of its most central puzzles: Why don't social things change more often and more dramatically? ${ }^{1}$ How sociologists answer this question, whether explicitly or implicitly, forms the contours of broader debates about ongoing inequality, the relationship between structure and agency, and the relative power of institutions and organizational routines. One important way to explain social reproduction has been through a mechanism that sociologists once called socialization.

Yet socialization, as a term, has fallen out of favor. At least within sociology, the word is most famously linked to the mid-century structural functionalism of Talcott Parsons, and both socialization and Parsons lost credibility in the political and epistemological upheavals of the 1960s and '70s (Stevens 2008: 106). For Parsons, socialization is "a particular part of learning" through which actors acquire "the requisite orientations for satisfactory functioning in a role" (1951:211), emphasizing the centrality of stability within his structural-functionalist sociology.

Scholars since then have applied a variety of similar concepts to explain social continuity, most notably Bourdieu's (1977) dialectical relationship between field and habitus, but also Foucault's (1990) synthesis of power and knowledge, institutionalists' study of organizational logics and institutional rules (Powell and Dimaggio 1991) and the various reconciliations of structure and agency found in Giddens (1984), Hall (2019) and Sewell (1992) (see also Lizardo and Strand 2010). There were also imports from other fields relevant to particular subdisciplines, such as Said's study of Orientalism (1979) and Butler's theory of gender performativity (1990).

Critics of Parsons's theory of socialization focused on his failure to account for power and agency, as well as his theory's teleology and incoherence. Yet in addition to these analytical criticisms, there were political problems as well. Around the same time Parsons was losing his prominence, the Moynihan report (Wilson 2009) and its arguments about a "culture of poverty" forced a reckoning with how strong theories of socialization could lead to "deficit thinking" (Valencia 2012) and victim blaming in accounts of racial and socio-economic inequality (Small, Harding, and Lamont 2010).

So much for socialization? Maybe not. In this review, we argue that all is not well in a post"socialization" sociology and that there is good reason to bring back a post-functionalist use of the term. We review the history of the concept, its high point under Parsons, the reasons for its demise, its continued use in some subfields (e.g., gender, education, and race and ethnicity), and the terms and concepts other sociologists now use to account for social reproduction. We then suggest that something is lost when we no longer use "socialization" or when its use remains isolated in particular subfields. Specifically, we emphasize the problems of history, power, and transferability in arguments about social reproduction that avoid using this term. We close by highlighting work that could move socialization in a post-functionalist direction. We suggest building off sociological work that engages cognitive science, linguistic anthropology, pragmatism, and the re-interrogation of values, and we encourage engagement with recent work in political science, philosophy, and sociology on the renewed importance of ideology and political socialization. We then pull the various criticisms of functionalist socialization together with our agenda for new directions to

\footnotetext{
${ }^{1}$ We are grateful to Omar Lizardo, Jessica Collett, Karen Cerulo, Iddo Tavory, Syed Ali, Bruce Phillips, and Zhu Li for helpful comments on earlier drafts of this manuscript. We are especially grateful to Anne Marie Champagne for extensive copy-editing and comments and to Isaac Jilbert for research assistance, data analysis, and graphic design.
} 
Whatever Happened to Socialization? (Forthcoming in Annual Review of Sociology)

By Jeffrey Guhin, Jessica Calarco, and Cynthia Miller-Idriss

suggest that Winchester and Guhin's (2019) article on normative frames provides one effective model for how to retheorize socialization.

\section{Life of the Concept}

Parsons and After

According to google ngrams, the word socialization and its German and French parallels, Sozialisierung and socialisation, were used occasionally in the early 1800 s but became much more common at the end of that century, paralleling the use of the word "sociology" itself. The second reference to socialization in the Oxford English dictionary comes from a Georg Simmel 1895 article titled simply "The Problem of Sociology." According to Giddings' 1897 book, The Theory of Socialization: A Syllabus of Sociological Principles, it was Simmel who "seems to have been the first writer to use the word 'socialization' in a definition of sociology," helping Giddings to argue that "the Theory of Socialization is the most important part of the Theory of Sociology" (1897: 1). Of the "founders," it was primarily Simmel and Durkheim who used the word socialization in the sense of social reproduction (Weber's and Marx's use of the term referred to something like collectivization).

Half a century later, it was Parsons who made the concept of socialization centrally important to American sociological practice. Linking Durkheim's (1973 [1925]) work on moral education to Piaget's (1965 [1932]) then-new theories of moral development, Parsons described how socialization is necessary for both moral and logical capacity (1951: 401; Alexander 1978: 123). For Parsons, socialization is critical for the maintenance of both social continuity and social order, as actors learn both to imitate and to identify with others, eventually learning their specific "role-values and symbol-systems" (1951: 238). Such learning for Parsons is necessarily interactive (Rawls and Turowetz 2019, meaning that "internalization" is not quite the same thing as socialization (1952:15), and that socialization might not always be successful, sometimes "requiring" social control (via other socialized forms of policing the self or others) or causing the experience of alienation (Parsons 1951: 211).

For Parsons, it is values themselves that drive social action and social continuity; many of his critics were more interested in the power that enforces such values, arguing that when structural congruity does exist, it is because of power rather than besides or before it (Cohen, Hazelrigg, and Pope 1975; Giddens 1968; Martin and Lembo 2020. These critiques, however, are criticisms more of Parsons and his lack of attention to power than of socialization as a concept or a process. When Parsons's critics offer implicit or explicit models of social reproduction, they are often not altogether different from the one Parsons described inasmuch as people come to internalize certain ways of understanding a social world through interactions with significant others within that social world; indeed they even use the word socialization, although the word is usually not central to any of the arguments' theoretical architecture (e.g. Foucault 1990: 104-105; Bourdieu 1984: 217, 440, 458, 474; Giddens 1984: 52, 170; Luhmann 1995: 240-244; for a phenomenological exception see Berger and Luckmann 1967).

These alternative models of social reproduction also tend to emphasize contestation over coherence. Wrong's (1976:48)'s arguments about “oversocialization," for example, emphasized how Parsons misread Freud and in so doing ignored the role of conflict within an individual's psyche, leading to an overdetermined and circumscribed understanding of agency. In light of these critiques, theorists developed models of social reproduction that explicitly left space for individuals to resist the 
influence of social forces, both internal and external. For example, Giddens (1984), and building off of his work, Sewell (1992), emphasize the relationship between agency and structures (as opposed to systems), and, with related concerns, Luhhman emphasizes the continual possibility of autopoesis (1995; Vanderstraeten 2000) while Archer focuses on the process of "morphogenesis" (1995).

These critiques of Parsonian socialization and its lack of emphasis on individual agency were taken up by other scholars, as well (Emirbayer and Mische 1998). For example, scholars of childhood describe previous theories of socialization as paying too little attention to the fact of childhood agency or the agency of others who are in the early phase of being socialized into a "system." Pugh argues that the word socialization "tends to obscure" potential conflicts and heterogeneity "with its undercurrent of implied determinism” (2014: 81; see also Corsaro 1992, 2017, Pugh 2009). Sociologists of organizations have similarly noted that traditional models of professional socialization can put too much emphasis on early training and not pay sufficient attention to the "embedded elaborations" that occur throughout a career (Everitt and Tefft 2018).

Other critiques of Parsons's model emphasized the importance of conflict as constitutive not only of the psyche but also of social life itself. While the "conflict" tradition need not be redescribed here, one of its most important, long-lasting, and still dominant proponents was Pierre Bourdieu (even if he would not have identified himself as such). Bourdieu described how contestations - as opposed to more abstract and conflict-neutral "values"-are both the source and outcome of the socializing process. Bourdieu was introduced to American sociologists in this "conflict" era of the 1970s and early 1980s (e.g. Bourdieu and Passeron 1977, Bourdieu 1977, Bourdieu 1984), and his work was narrated explicitly in contrast to "functionalism" (Collins 1971). Alongside Bourdieu, the late 1970s debuted other key counterarguments to functionalist socialization, especially within the sociology of education (Mehta and Davies 2018): Collins, for example, focused on the arbitrariness and systemic power of credentialism (1979), while Bowles and Gintis brought a renewed Marxian focus on class reproduction (1976).

The critique of Parsons's insufficient attention to agency is paralleled by a critique of insufficient attention to heterogeneity. In West and Zimmerman's (1987) germinal discussion of "Doing Gender," they describe the many problems with "sex role socialization"—one of Parsons's ongoing Freudian concerns - especially the idea that sex roles and gender identities are "achieved" by a young age and then remain "fixed, unvarying, and static" (1987: 126). In contrast, they pull on both Goffman (1959) and Garfinkel (1967) to emphasize how gender is an ongoing interactional achievement. While not quite as focused on Goffmanian interaction, Swidler's (2003) immensely influential work on cultural repertoires shows how any one person has a multitude of heterogeneous cultural tools that become useful to solve discrete problems.

Whether focusing on power, agency, or heterogeneity, these critiques come together in criticisms of the effects functionalist theories of socialization can have, especially on scholarly assumptions about the source of inequalities faced by marginalized communities. For example, the culture (or subculture) of poverty thesis suggests that it is the socialization of certain values which explains intergenerational poverty. Highlighting the role of culture (and its socialization) allows intellectuals, politicians, and activists to deny-or at least obfuscate_-other mechanisms that have maintained inequality, especially racism and resource hoarding (Golash-Boza 2016, Lewis and Diamond 2015, Seamster 2015, Tilly 1998). 
The most lambasted of the culture of poverty arguments are the collected works of Oscar Lewis (1959; though see Harvey and Reed 1996 for an analysis of Lewis as anti-capitalist rather than culturalist) and the Moynihan report, The Negro Family: The Case for National Action (1965; Gans 2011; Wilson 2009). Socialization is central for Lewis and, especially, Moynihan, who centers the role of the Black family because "the family is the basic social unit of American life; it is the basic socializing unit" (1965: 5). Moynihan argues that "the disorganized family has failed in its function as a socializing agency [and so] it has handicapped the children in their relations to the institutions in the community" (1965: 48). While Moynihan was not opposed to structural solutions to racial inequality (indeed this was the goal of his report), his argument has been useful for those who insist-however empirically inaccurately — that poverty is exclusively, or at least primarily, a problem of culture. And it is socialization, they argue, that makes culture such a problem.

Recent debates about these questions have resisted outright dismissal of cultural arguments (Wilson 2010). Instead, scholars insist that culture is much more complex and heterogeneous than earlier theories might have acknowledged. For example, scholars like Small, Harding and Lamont (2010) call for a reconsideration of the relationship between culture and poverty, implicitly also calling for a theory of socialization that can account for the heterogeneity and agency many found lacking in Parsons.

\section{Mapping the Decline of Socialization}

To better understand the consequences of anti-functionalist critiques of socialization, we mapped the use of the term across generalist and subfield journals over time. To validate our understanding of the rise and fall of the use of socialization in sociology, we conducted a search for the usage in Web of Science (WoS) and JSTOR. The WoS search was a topic search for socializ* or socialisation, covering abstracts, titles, keywords and the WoS "keywords plus" feature, which gave us a universe of terms in order to analyze the larger body of 'socializations' usage. Due to sub-ideal coverage in WoS for all journals of interest, we also searched via JSTOR for particular subfield journals. Duplicates were removed from the database. In total, we captured 708 articles that used the term socialization (or a variant, such as socialize) across thirteen journals, starting in 1912. This included the three flagship sociology journals (American Sociological Review, American Journal of Sociology, and Social Forces) and ten specialty journals. As Figure 1 reveals, the use of the word socialization and similar terms first peaked and fell at roughly the same time as structural functionalism, though the use of the term has been more persistent in specialty journals such as Sociology of Education and Ethnic and Racial Studies. Social Forces has also seen a recent uptick in use of the term, though still not close to its functionalist peak ${ }^{2}$. For a full list of the journals and more on instances of usage, see our online appendix.

\section{[FIGURE 1 ABOUT HERE]}

\footnotetext{
2 We date the "functionalist peak" by using google ngrams to trace "Talcott Parsons" (a steady rise from around 1940 to 1970, at which a steep decline begins). The phrases "functionalism" and "structural functionalism" show a steady increase, though this might be because they are discussed negatively after a certain point. However, Parsonian language such as "social value-orientations" shows spikes in 1951, 1965, and 1978, then steady decline. This description of Parsonian functionalism peaking and then abating is widely described in the literature; see, for example, Stevens (2008).
} 
While use of the term socialization has declined since its functionalist peak, this does not mean that the term has been abandoned entirely. Rather, as we see in Figure 1, the term has continued to be used, and in some cases has even increased in use in some subfield journals. That includes Ethnic and Racial Studies and Sociology of Education, which are now the two sociology journals in our analysis where the term is most likely to be used. This finding is important for two reasons. First, it suggests that research centering the concept of socialization has largely been pushed out of generalist sociology journals and into subfield journals. Second, and as we will discuss in a subsequent section, this pattern points to the continued usefulness of the term socialization for making sense of situations in which a person is brought into a social world not entirely of their own choosing and over which they lack a significant amount of control. That includes students in classrooms, children in families, and people of color in primarily white settings.

We suspect that socialization has continued to be used in these cases because they involve massive imbalances of power that make socialization quite apparent. In a 2017 Sociology of Education article, for example, Heidi Gansen uses ethnographic observations in preschool classrooms to examine the "gendered sexual socialization children receive from teachers' practices and reproduce through peer interactions" (255). Gansen reveals how, through teachers' responses to children's behavior (e.g., heterosexual romantic play, bodily displays, and unwanted touching), children learn that "boys have gendered power over girls' bodies" (255) and then reproduce those understandings in interactions with teachers and peers. Similarly, a 2016 Ethnic and Racial Studies article by Quaylan Allen uses interviews with Black men and their sons to examine how fathers prepared their sons "for encounters with racism" and also "modelled to their sons how to navigate racialized spaces as black men" (1831).

\section{Alternatives to Socialization}

Even as the use of socialization declined and shifted to specific subfield discussions, sociologists still needed ways of talking about the key processes and phenomena of social reproduction. These scholars strove to disentangle the many subtle and complex ways that people receive, resist, negotiate, reject, and creatively make use of the messages they encounter in society, providing greater depth to the study of social reproduction than is available in more unilinear models of social reproduction.

Bourdieu's work has been helpful for many scholars as an alternative to functionalist models of socialization. Bourdieu's language has also served as a tool for other scholars to use in pushing against reductionist explanations of the link between culture and poverty, such as Carter's (2005) "nondominant cultural capital." And yet, while these scholars might use Bourdieusian terms like habitus, capital, or field, they all imply something like socialization, even without using the word, or using it only in reference to other scholars' use of the term (e.g., Gaddis 2013, Sallaz 2014). A few studies of culture and inequality do combine discussions of Bourdieu while explicitly describing "socialization," including Bonilla-Silva, Goar, and Embrick's (2006) study of how racial residential and social segregation "furthers a socialization process refer to as 'white habitus" (229), Calarco's (2018) study of different forms of help-seeking behavior in working-class and middle-class students, Lewis-McCoy's (2014) study of the processes by which white parents hoard opportunities in racially diverse suburban schools, and Dumais's (2002) study of gendered participation in cultural activities among high school students. 
Similarly, while Lareau (2003) uses the term "socialization" in her Bourdieusian analysis of social class differences in family life, she uses it sparingly. As she explains in a footnote:

In this book, I primarily use the concept of child rearing, but at times I also use the term socialization. Many sociologists have vigorously criticized this concept, noting that it suggests (inaccurately) that children are passive rather than active agents and that the relationship between parents and their children is unidirectional rather than reciprocal and dynamic.... Nonetheless, existing terms can, ideally, be revitalized to offer more sophisticated understandings of social processes. Child rearing and socialization have the virtue of being relatively succinct and less jargon laden than other alternatives. As a result, I use them" (Notes to Pages 4-7; fn. 3).

Despite these benefits, however, and given the pushback that Lareau describes, most efforts to reconcile culture and poverty find replacement words for socialization.

Scholars of youth and peer cultures have also pushed back against a functionalist model of socialization and, in doing so, offered alternative ways of talking about similar processes (Milner 2013). For example, British sociologist Willis (1981) used Marxian analysis to criticize how "mainstream sociology... with its notion of socialisation, and its implication of passive transmission, misses the tension and uncertainty" of social reproduction (1981: 183). In his classic ethnography, he examined how working-class "lads" in England created a culture of resistance that protected them from feelings of failure in school while simultaneously reproducing working-class outcomes. The generation of cultural studies research that came out of the Birmingham school of cultural studies similarly showed the critical role that subcultures and scenes play in developing youth and adolescent style, modes of communication, use of symbols, and propensity to violence (Beier 2016; Goldstein and Kadlubov 1998; Muggleton 2000; see also Corsaro and Rizzo 1988, Fox and Miller-Idriss 2008). Such work refined our understanding of the fluidity of social reproduction processes. Social reproduction was not merely characterized by a bimodal distribution of successful incorporation versus deviance, such scholars argued, but was better represented by fragmented and circuitous routes to adulthood that had many pathways and off-ramps on the way to various outcomes.

Finally, the study of social interactions, one of the oldest traditions in United States sociology, has emphasized how people habituate certain behaviors via local organizational routines and interactions. The two most emblematic of these arguments are Howard Becker's (1953) study of "becoming a marihuana user" and Erving Goffman's (1961) study of the "moral career of the mental patient," both of which inspired future sociologists to use "becoming a..." and "career of..." as templates for title and form. These arguments differed in important ways from the functionalist model, rooted in both methodological commitments to in situ meaning-making and theoretical suspicions of internalized values or characteristics as the drivers of social action. Instead, these authors emphasize that a sense of self and an understanding of the world are always an interactional achievement not necessarily predicted by anything internal to the actor before the situation, stimulus, or organizational form in question. Habituation is therefore not a working out of internalized norms but rather an alignment of organizational routines and significant others' definitions of the situation with actors' own habituated interpretations of their experiences. As such, this thing-like-socialization, echoing the authors' pragmatist influences, is always contingent and subject to change.

While these alternative models of social reproduction are not necessarily irreconcilable with the idea of socialization, they are quite distinct from the simplified unilinear model that functionalist socialization has come to represent. As such, these approaches represent longstanding critiques of 
the functionalist model extending all the way back to Becker and Goffman's mid-century work. The critiques come together in a broader push to see individuals as agentic, active interpreters of their social and cultural worlds (Corsaro 1992; Corsaro and Rizzo 1988; Griswold 1987), often through emphasizing the centrality of practices and embodiment (Wacquant 2004, Lizardo 2009). Decades after the demise of functionalism, it is worth considering what these newer concepts are successful at capturing and what they miss. What, if anything, was lost as socialization fell out of favor? How might socialization still have value for sociology?

\section{What Gets Lost Without Socialization}

While various theories of social reproduction can accomplish much of what the term socialization is intended to do, we argue that key pieces are still lost, including historicity, transferability, and a sensitivity to asymmetries of power. Of course, some might say these very deficiencies characterized functionalist models of socialization, and to some degree this is our point: functionalist socialization is not the only game in town.

\section{Losing Power}

As noted above, our analysis of the use of "socialization" in sociological journals reveals that studies of gender, race, sexuality, and class continue to emphasize the word socialization, especially outside of the central journals of the American Sociological Review and the American Journal of Sociology. We suggest that part of the reason socialization has maintained its usefulness in these subfields-in contrast to similar terms like mediation or negotiation or habituation-is that "socialization" is able to engage the ongoing asymmetries of power through which structures of oppression are reproduced (e.g. Bonilla-Silva et al. 2006; Burt, Simons, and Gibbons 2012; Gansen 2017; Hagerman 2013). Certainly, the role of power within social reproduction can be explained using other language, most prominently Bourdieu's dialectical relationship between field and habitus. And it is fair to say that previous iterations of socialization, especially those with a more functionalist bent, were insufficiently sensitive to the role of power in reproducing social life.

Yet the concept of socialization captures something important about being brought into a social world not entirely of your own choosing and about which you lack a significant amount of control. Scholars of systematically marginalized identities and communities are acutely sensitive to how agentic and creative those within their studies can be, yet they are also aware that institutions like race and gender are so powerful that such agency and creativity can only go so far. As such, the study of "racial socialization" remains critical in analysis of families (Hodge-Freeman 2015, Banks 2012), parenting (Allen 2016; Dow 2016; Gonzalez 2019; Hagerman 2013; Butler-Barnes, Martin \& Boyd 2017), politics (Nunnaly 2010), and segregation/discrimination (Bonilla-Silva et al. 2006; Burt, Simons, and Gibbons 2012). In a much-cited article (2006), Hughes and her co-authors describe how parents of various races and ethnicities socialize their children pointing out different mechanisms of enculturation, bias, mistrust, and egalitarianism while asking how certaincharacteristics of families, parents, and children might differently affect when and how socialization occurs.

Besides racial socialization, there is also the question of how racial minorities are affected by broader socialization efforts. In her study of Black students in elementary schools, Tyson shows how schools" "hidden curriculum" of cultural socialization does harm to young Black children, emphasizing behavioral regulations "to transmit to [B]lack students dominant cultural norms to 
which they were expected to conform both in school and in the wider society" (Tyson 2003: 332). Similarly, Shedd acknowledges in her study of four Chicago public high schools that "society as a whole benefits when schools accomplish their missions of socialization and acculturation" (2015: 33). Yet the nature of that socialization can be alienating rather than empowering, particularly regarding students' growing awareness of the injustice inherent in a stratified social order. Parsons himself insisted that socialization did not make everyone the same; indeed, part of the function of socialization was to recognize and accept one's relative status and rank. The difference, as Shedd argues in her discussion of how encounters with police socialize young people, is that for her, socialization does not mean adapting oneself to a social order so much as it means becoming reflexively aware of the problems with that order and how its benefits are not distributed equally (2015: 155).

Other scholars have continued to use socialization as well. Sociologists of sex, gender, and sexuality have emphasized the role of socialization (Carter 2014, Pascoe 2013, Gansen 2017, Garner and Grazian 2016, Perry 2015) even as they have adapted the concept following earlier critiques, especially those of West and Zimmerman. Connell's (2015) classic work on masculinities uses the word socialization but makes clear such socialization is not necessarily harmonious and is always subject to change given new socializing institutions, organizations, and situations. Likewise, Risman and Davis (2013) show how socialization has problematic connotations, especially with its historical connection to "sex roles," yet is also a necessary mechanism for how "gender as structure" reproduces itself. Similarly, scholars of migration and nationalism have continued to find it useful to use the term socialization to describe how migrants and their children are affected by their destination country (Röder 2015, Landolt and Goldring 2009), even if many use similar though not identical terms like "assimilation" instead (Waters and Jiménez 2005). Finally, scholars of class distinction continue using the word socialization to describe how different classes teach young people (Sing-Manoux and Marmot 2005, Calarco 2018) or new members of an organization (Leby and Sasson-Levly 2008) how to interact with their social world. One of the most famous (and controversial) scholars of the socialization of class difference, Basil Bernstein (2003), never abandoned the term throughout his prolific career.

For scholars studying systems of race, gender, class, migration, and sexuality, as well as those studying other powerful institutional identities, the term socialization usefully emphasizes how these identities are developed and rendered powerful in ways beyond any one actor's control. For some of these scholars, socialization is also a useful concept for highlighting the competing influence of different and intersecting sources of socialization in individual lives (e.g., for queer immigrants and queer people of color) (Romero 2017, Ocampo 2013). We suggest that the ongoing use of socialization within each of these subfields points to the terms' continued utility in analyses of how power imbalances develop via the internalization of group processes.

\section{Losing History}

Without socialization, it is easy to lose sight of how people came to know the culture they know. When scholars focus on the incoherence of culture or on people's agency in cultural processes, culture can sometimes be described as simply "available" (Tavory 2010). The sources of people's strategies and cultural tools are left relatively unexplained. Certainly, the fact that people know more culture than they use (DiMaggio 1997, Swidler 1986) is an important rejoinder to functionalist models of socialization, yet other conceptualizations of socialization can simultaneously acknowledge that culture is heterogeneous and recognize how culture's constraints are historically 
situated and rooted in differences of power. To be clear, how people learn culture is not the same thing as historical change (Sewell 1992), by "losing history" we mean losing focus on the historical processes through which certain culture became available or unavailable, salient or not salient.

Of course, no project can or should answer every question. Not everyone seeking to explain or understand particular actions has to provide their historical and biographical basis as well. Yet the net effect of centering agency and heterogeneity can be an inordinate focus on how culture works rather than why (Vaisey 2014), of what people do in certain contexts rather than how it came to be the case that these are the ways they have learned to act. Yet questions of socialization remain: how are people socialized into situational codes, and how do they come to prefer certain situations over others? How do they learn to adjudicate the successful completion of a situation, or even to know what success would be (Winchester and Guhin 2019)?

\section{Losing Transferability}

Without socialization, it is also more difficult to see the parallels between learning processes described in different academic disciplines. Bourdieu's model of social reproduction, for example, tends to replace the concept of socialization with his "somewhat idiosyncratic, and in many ways unwieldly theoretical vocabulary-one that has never been coherently incorporated into Anglophone cultural analysis" (Lizardo 2017: 89). While terms like "cultural capital" and "habitus" have been exported as individual units from Bourdieu's oeuvre, these concepts lose much of their analytical heft when they are isolated from Bourdieu's overall theory of the field. As such, Bourdieu's vocabulary takes a long time to learn and understand, making its usage much more likely to remain within the particular subfields of sociology where it is most widely understood.

Indeed, even if Bourdieu's individual concepts have diffused quite widely across sociology, these terms are not necessarily well-known outside of sociology and neither are the terms used together in the way that can explain socialization rather than socialization's effects. Cultural capital, for example, is an important concept that can explain why and how certain people connect to others, but without field, habitus, and a bevy of other concepts, the term loses the historicist precision of Bourdieu's overall project. There is also the problem that Bourdieu's vocabulary has a Hobbesian war-of-allagainst-all baggage attached to it, perhaps running the risk of moving too far from a Parsonian optimism into a Nietzschean (or at least Pascalian) pessimism (Alexander 1995, Gorski 2016).

Such linguistic ambiguity, and the insularity it generates, has been a problem with many terms developed as alternatives to socialization. In his writing on childhood socialization, Corsaro argues that other scholars of socialization, especially Parsons, ignore children's agency in interpreting and often resisting the influence of the adult world. Based on his empirical work in preschools, Corsaro shows how socialization occurs not as the private internalization of externally imposed values, norms, or habits, but rather through a "social and collective process" of "interpretive reproduction" (1992: 161; see also Corsaro and Rizzo 1988) most conspicuous in peer group interaction. Yet Corsaro also makes clear that there are many ways to conceptualize the term, preferring constructivism, "a model of socialization in which the child is seen as an agent and eager learner" (2018: 398). Ultimately, however, Corsaro's (1992) notion of "interpretive reproduction" has never really taken root outside the sociology of children and youth. Thus, although other terms might not share the baggage unique to socialization, they are plagued by the problem of new language, in that it takes time and collective agreement before they can be widely understood and adequately applied. 
Socialization, as a term, does not have this problem of transferability. Of course, the specific usage of the term, and the phenomena to which it is applied, might vary across different fields and subfields. But we would argue that, even if those uses are not perfectly consistent, having a shared terminology allows scholars from different subfields and disciplines to recognize similarities in their work. So, even though new terms can provide new insights, it also the case that too many new terms - rather than adaptations of old ones — can make the discipline's theoretical core unwieldly and, ironically, ungenerative (Besbris and Khan 2017). The usage of local language is obviously not a problem in the sciences, and it is by no means unique to sociology, but to the degree that sociologists want to speak across subfields and even to other academic disciplines, it will be useful to settle on common terms (Vaisey and Valentino 2018). Socialization is one such common term.

\section{Reimagining Socialization}

In outlining what is lost without the term socialization, we do not argue that sociologists should embrace a functionalist model or definition of socialization. Rather, our point is to suggest that, because of the term's broad recognizability across fields and subfields, its usefulness for speaking about the origins of culture, and its sensitivity to problems of power, there is value in imagining a post-functionalist approach to socialization-one consistent with the continued use of the term in research on asymmetries of power. In the same way that the words culture and gender do not mean what they meant 50 years ago, there is no reason to assume socialization must as well.

\section{New Directions in Socialization Research}

If sociologists do choose to reimagine and reembrace the term socialization, what might that agenda look like? How would it differ from earlier approaches? We suggest a few additional lines of research that could further recenter socialization while being sensitive to the importance of heterogeneity, power, and agency.

\section{Socialization from Minds and Society to Bodies and Brains}

The past 30 years have seen a rapid growth in sociological interest in cognition (Zerubavel 2009. Lizardo and Strand 2010), with an increased focus on the role of neuroscience (Cerulo 2010) and psychology (Miles, Charron-Chénier, and Schleifer 2019) in explaining sociological phenomena. Perhaps because the term socialization has not met such dramatic opposition in psychology and social psychology (including sociological social psychology, e.g. Elder 1994, Garner and Grazian 2016), these works often continue to use the concept of socialization, although often with a much sharper focus on specific process of cognition and embodiment. For example, Luft's work shows how cognitive distinctions that make enemies into moral "others" are not so much the causes of killing but rather that the result of killing, part of "unfolding processes of combat socialization and in turn dehumanization" (2015: 66).

Luft's work is part of a growing set of ethnographic and theoretical works that examine "secondary socialization," that is, the socialization of adults (Lizardo 2018). Another example of this genre is Winchester and his coauthors' series of articles on adult converts to new social settings (Winchester and Green 2019, Winchester 2016), each emphasizing how embodied cognition (Shapiro 2019) align people's various expectations of themselves with their various surroundings. 
Whatever Happened to Socialization? (Forthcoming in Annual Review of Sociology)

By Jeffrey Guhin, Jessica Calarco, and Cynthia Miller-Idriss

In different ways, these works draw on the "dual process framework" of culture (Lizardo et al. 2016). This framework stems from Vaisey's (2009) work on motivation and justification but has also generated significant debate regarding the distinctions between thinking discursively versus thinking practically (Vaisey 2009) and knowing how versus knowing that (Lizardo 2017).

In his call for an improved cultural analysis, Lizardo (2017) attempts to bring together many of these distinctions. He describes how cultural knowledge is individually "enculturated," making different kinds of culture differentially, sometimes redundantly, available to an actor. Yet, as he later wrote "contemporary culture and cognition scholars in sociology have seldom laid out explicitly what are the consequences of taking cognition seriously for understanding socialization processes" (2018). By emphasizing a more embodied understanding of both cognition and socialization (Toren 1999), Lizardo provides a way for the concept of socialization to overcome many of the criticisms of the functionalist model described above.

\section{More Insights about Embodiment from Linguistic Anthropology and Conversation Analysis}

Scholars of language acquisition and usage are necessarily interested in socialization. The learning of a language, especially a first language, involves precisely the kinds of power imbalances and limited control often implied by the term socialization. Yet recent research reveals that language socialization is not as obviously one-sided as it may appear. Linguistic anthropologists, linguists, and scholars of conversation analysis (Toren 1999, Brown and Gaskins 2014) have shown how language acquisition and ability are managed with more agency, heterogeneity, and historical contingency than a functionalist model of socialization would allow.

Central to these insights is the counterintuitive insistence that language is neither the central model nor the primary mechanism of culture. Following this insight, scholars - even linguistic anthropologists - recognize that they need more than words to understand meaning. To know what and how things mean might well begin by looking at words and the patterns in which they appear, but it is what comes before, after, and alongside words that scholars of language have recognized as even more fundamental (Ochs 1999, Goodwin 2018). Even conversation analysis (Stivers, Sidnell, and Bergen 2018) has come to appreciate that many of the most important ways in which meaning is communicated, understood, and experienced are not only subconscious (which is not necessarily difficult for a Parsonian to acknowledge) but also embodied and situational in ways that necessarily relate to the material space of the physical world (see also Bourdieu 1977, Taylor, Stoltz, and McDonnell 2019). Language acquisition and usage are embodied experiences, rooted in deep evolutionary adaptations that precede dangling modifiers by millions of years (Tomasello 2009).

Future sociological work on socialization can build off of these insights by examining how other social processes are socialized within and alongside language itself and all the many social processes that undergird and go alongside the development of language. Indeed, this insight is already present in classic sociological work on how children learn about race and gender alongside racism and sexism (Feagin and VanAusdale 2001, Thorne 1993).

\section{Being Pragmatic About It}

The pragmatist revival (Schneiderhan 2011, Joas 2000, Jansen 2017) in recent sociological work builds on sociology's relationship to pragmatism all the way back to the Chicago school through the work of Becker and Goffman and maintained most notably in symbolic interactionism and certain 
forms of ethnography. What distinguishes this new pragmatist sociology is its more explicit acknowledgement of influences, especially an emphasis on John Dewey's theory of habits (Camic 1986).

In many ways, pragmatist socialization might seem a contradiction in terms. The functionalist roots of the term socialization make it seem bound to a commitment to shared "goal attainment," which directly contradicts a Deweyan focus on ends-in-view rather than ultimate ends (Dewey 1958 [1922]: 223). Yet Dewey, a scholar of childhood and education, continually emphasized habits as a central component of both social life itself and any attempt to understand it. The difference is that habits are always means rather than ends, thus requiring and, in fact, creating a reflexivity that is both necessary for meaningful social interaction and somewhat inevitable given the tendency of habituated action to run into obstructions (Miettinen, Paavola, and Pohjola 2012). Critics of pragmatism argue that its focus on innovation and changing-of-habits can sometimes go too far (Rawls 2011: 280), making it more difficult to account for social reproduction. And yet pragmatism, especially as worked out by John Dewey, is not so much opposed to continuity as it is continually aware of its capacity for rupture (Gross 2018).

\section{The Value of $V$ alues?}

Recent work on values and norms offers a useful direction for recentering socialization in sociology. Critics of functionalist socialization emphasize the problems of focusing too centrally on values and norms as the engines of social reproduction, thereby ignoring power, agency, and the possibility that values and norms themselves are constantly shifting and heterogeneous (Swidler 2003). Yet recent work has shown that sociologists' use of values and norms to explain social action can account for the complexity, agency, and power that Parsons and other functionalists have missed (Hitlin and Pilliavin 2004, Horne and Molborn 2020).

In his call for the "(re)genesis of values," Miles (2015) references Joas's (2000) pragmatist reinterpretation of a sociology of values to build off of Schwartz's (2010) work on the structure of values and critiques of Parsonian action theory to argue that values are "causally linked to behavior" (2015: 698). However, in contrast to "consensus-oriented, often tautological functionalist work on values," he suggests a "cognitively plausible, empirically supported framework that can accommodate conflict and consensus" (2015: 699) by situating values in the automatic cognition described in dual process models. While Miles does not explicitly engage the question of socialization, his argument that values are part of our habituated, "automatic" consciousness suggests an important place for socialization in values research (Hitlin 2011; though see Martin and Lembo 2020 for a critique of "values").

\section{Political Socialization and the Renewed Importance of Ideology}

Political scientists' work on ideological socialization also offers insights for recentering socialization in sociology. Despite facing critiques similar to those in sociology, political scientists have managed to revive socialization research in the past twenty years (Nieme and Hepburn 1995, Sapiro 2005). Political scientists, like sociologists, learned to pay more attention to the heterogeneity within and conflict between various socializing influences, also emphasizing the role of young people and newcomers to institutions not only as receivers of political beliefs and practices but also as political actors in their own right. 
In their re-envisioned models of socialization, political scientists leave ample room to examine problems of inequality and power. Unsurprisingly to sociologists of racism and sexism, political scientists find that political socialization is a deeply gendered and racialized set of processes. Bos and her coauthors (2012) describe how, even in elementary school, boys express greater interest in politics and deeper political ambition than girls. Similarly, work on immigrant political socialization (Landolt and Goldring 2012) shows how immigrants' politics - and the socialization of immigrants' politics - is not simply a question of general or segmented assimilation but rather a series of complicated, "multi-layered" interactions. While some of this work on political socialization has been undertaken by sociologists (McFarland and Thomas 2006), sociology still has much to add. Sociological work may also be particularly useful in answering the call for more intersectional work on these topics, especially on racial and political socialization (Nunnally 2012).

Political sociologists' renewed interests in ideology (Jost 2006) also offers an important opening for socialization research. Much of the current work focuses on ideologies related to white supremacy (Bonilla-Silva 2003) and patriarchy (Manne 2017). While the reproduction of ideology is a classic concern of Marxian analysis (e.g. Althusser 1971), the contemporary study of ideology has been primarily focused on describing how ideology works rather than how it is reproduced across time. This gives sociologists another important new direction in which they could take the study of socialization.

Toward a New Theory of Socialization

There are many possible permutations of these new directions and criticisms, and to give these various moving pieces due consideration would require more space than we have here. However, we end by suggesting Winchester and Guhin's (2019) study of "normative frames" as one theory of socialization that incorporates the criticism and new directions we describe above. The article critiques Swidler's (2003) theory of cultural tools by drawing on Goffman and Dewey to develop a theory of "normative frames." Actors learn and embody these frames, thereby developing successful capacities for understanding when and how to use certain practices, as well as how to adjudicate whether that practice has been successful.

Through using the cases of students at an Evangelical high school and recent converts at an Evangelical church, the authors show how Evangelical prayer is a "cultural tool" in the way that Swidler describes, but it is a tool whose success becomes legible and achievable through learning the local context of a certain organization and putting oneself under the power of that organization (consciously or unconsciously). While Winchester and Guhin do not emphasize power or politics in this piece, these additions could be easily made to a model that already includes much of what we have been discussing - including pragmatism, normativity, embodiment, and organizational history - and which they describe as applicable to many other social institutions, including marriage and celebrity.

Such a new theory of socialization is not limited to "cultural tools" or institutions: instead, what is important is the way that people habituate particular means of normative evaluation, done so within a context that is simultaneously morally imbued and marked by asymmetric power. These socialization processes are then helpful to explain a wide variety of micro-level processes with mesoand macro-level implications, not dissimilar from Parsons' own concern with explaining structural congruity via local interaction, yet with a readier capacity to recognize the heterogeneity, power, and history lacking in functionalist accounts. 
Whatever Happened to Socialization? (Forthcoming in Annual Review of Sociology)

By Jeffrey Guhin, Jessica Calarco, and Cynthia Miller-Idriss

\section{Conclusion}

The concept of socialization often brings with it all the problems associated with structural functionalism: a lack of attention to history and heterogeneity; an obfuscation and reification of power imbalances, and an incapacity to recognize conflict as constitutive. So why keep socialization if it has all this baggage? Couldn't scholars of socialization do their work without the word (Nash 2015)?

The short answer is yes, of course they could. And they have been. To drop the word socialization entirely would not put an end to the sociological study of social reproduction, and neither would it permanently mar our capacity to explain social life. However, we argue that bringing the concept (and word) socialization back into the sociological mainstream would do more good than harm. We suggest that many of the criticisms of the word socialization are actually criticisms of structural functionalism, and that socialization is already being used by scholars across the social sciencesincluding many sociologists - in ways that overcome those problems. Such research actively embraces the term socialization and uses it to emphasize historicity, the overarching power of social structures, and the importance of transferability to other academic disciplines.

Certainly, there is still work to do, and we suggest that developments at many of sociology's borders have either themselves emphasized socialization or are ideally located for such interventions. These borders include sociological interactions with cognitive science, pragmatism, the social psychological study of values, and the renewed focus on political socialization and ideology in political science and philosophy. Through each of these settings, and in many more, particularly the study of racial and gender socialization, sociologists can develop a theory of socialization that is at once pithily transferrable to other academic disciplines and sociologically sensitive to older problems with the term.

To be clear, there is still a lot to figure out about the processes and mechanisms within socialization, and these are questions for which replacements to socialization-including the work of Pierre Bourdieu — can be quite helpful. Yet these insights can happen within a broader paradigm of socialization rather than as a replacement of it. After all, scholars of socialization have more agency than was previously believed. 
Whatever Happened to Socialization? (Forthcoming in Annual Review of Sociology)

By Jeffrey Guhin, Jessica Calarco, and Cynthia Miller-Idriss

Figure 1:

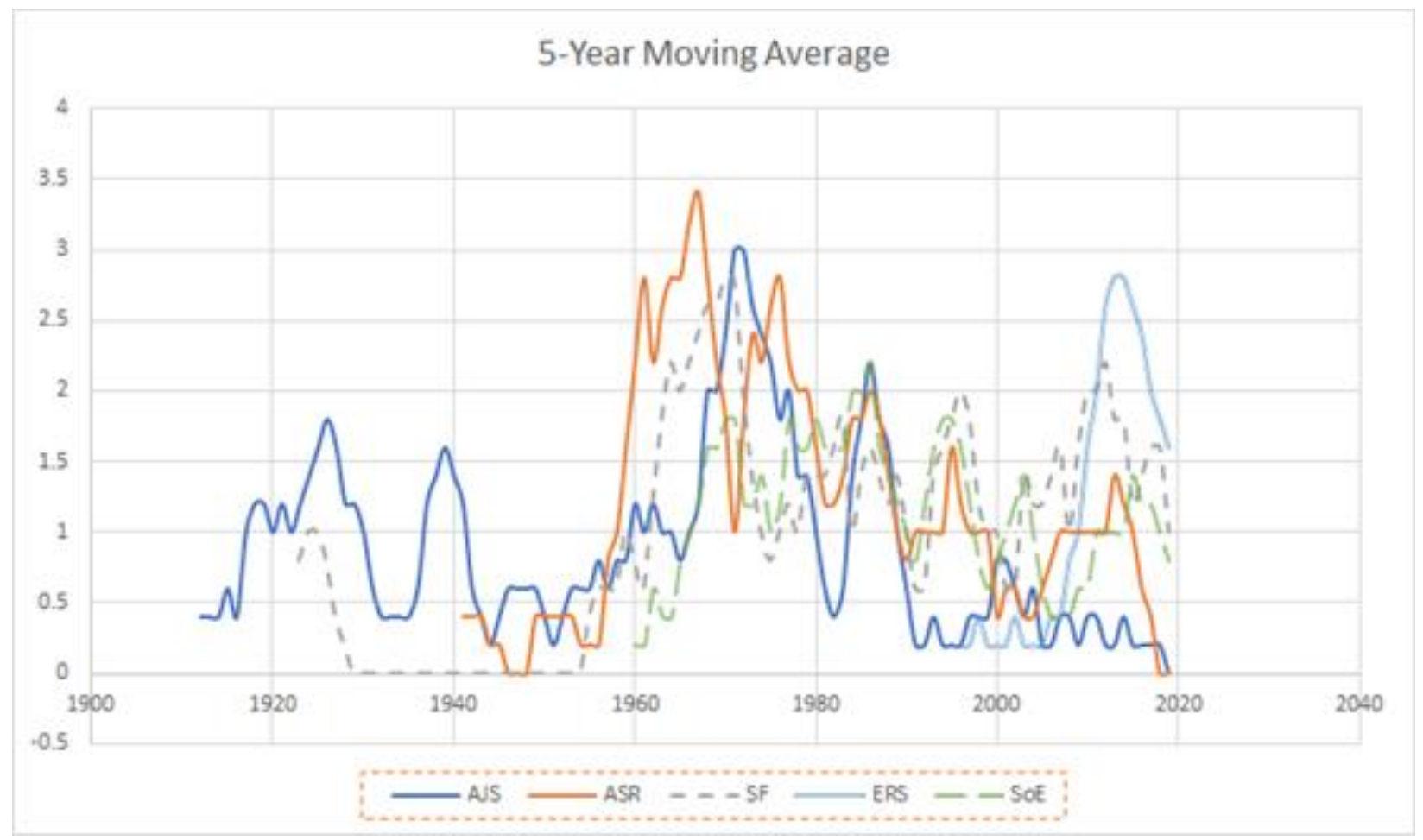




\section{Eight Summary Points}

1. The concept of socialization is a central set of mechanisms for early models of social reproduction, representing the social processes that bring people in line with the status quo.

2. Like the functionalists who introduced the concept, socialization has fallen out of favor, critiqued for its lack of attention to power and agency, for its teleology and incoherence, and for its link to misguided "culture of poverty" arguments that blame victims and support "deficit thinking."

3. Analyses of Web of Science and JSTOR articles in key sociology journals, from 1912 through 2020, reveal that peak use of the term socialization roughly coincided with the high point of structural functionalism, then precipitously declined. In the American Sociological Review and the American Journal of Sociology, the term's use has remained low; appearances of the term have been more persistent in Sociology of Education and Ethnic and Racial Studies, with Social Forces also seeing a recent uptick in use of the term, albeit still far below its functionalist peak. These findings suggest that discussions of socialization have been pushed out of the most "prestigious" generalist journals and into subfield journals instead.

4. As "downloading" models of socialization fell out of favor, sociologists developed alternative terms and concepts to account for social reproduction. That includes Bourdieu's model of habitus and cultural capital, Willis and others' work on resistance, work by Becker, Goffman, and others on habituation and interaction, Corsaro's concept of interpretive reproduction, and work in nationalism studies on how national identities are developed and reinforced through banal, everyday activities.

5. While alternative theories of social reproduction can accomplish much of what the term socialization is intended to do, we argue that key pieces are still lost, including historicity, transferability, and a sensitivity to asymmetries of power. Of course, some might say these very deficiencies characterized functionalist models of socialization, and to some degree this is our point: functionalist socialization is not the only game in town.

6. Consistent with our argument, we find that studies of gender, race, sexuality, and class continue to emphasize the word socialization, and they do so in part because the term engages the ongoing asymmetries of power through which structures of oppression are reproduced. Essentially, the concept of socialization captures something important about being brought into a social world not entirely of your own choosing and about which you lack a significant amount of control. Scholars of systematically marginalized identities and communities are acutely sensitive to how agentic and creative those within their studies can be, yet they are also aware that institutions like race and gender are so powerful that such agency and creativity can only go so far.

7. Because of socialization's broad recognizability across fields and subfields, its usefulness for speaking about the origins of culture, and its sensitivity to problems of power, there is value in imagining a post-functionalist approach to this term. In the same way that the words culture and gender do no mean what they meant 50 years ago, there is no reason to assume socialization must as well.

8. A post-functionalist agenda for socialization research would bring the concept back to the center of the discipline, particularly as a mechanism for reinforcing and resisting systems of oppression. Future socialization research could also build off sociological work engaging cognitive science, linguistic anthropology, pragmatism, and the re-interrogation of values. Speaking to recent work in political science, philosophy, and sociology, socialization research could also examine the development and reinforcement of ideology in political socialization. 


\section{Four Future Issues}

1. Continued research on socialization and its relationship to systems of oppression should not be isolated in subfield journals but rather should have a place of prominence within the discipline as a whole. Specifically, sociology should pay greater attention to research on socialization as a mechanism for both reinforcing and resisting systems of oppression.

2. Speaking to the intersection of neuroscience, psychology, and sociology, future research should consider the role of cognition in socialization, examining how different forms of thinking show up in the first place. This work could build on Lizardo's (2017) call for an improved cultural analysis and also use tools from linguistic anthropology and conversation analysis to consider how socialization occurs within and alongside language.

3. Recent work on values, norms, an ideology offer insights for recentering socialization in sociology. Recent work in this area has attended to the heterogeneity within and conflict between various socializing influences and also emphasized the role of young people and newcomers to institutions not only as receivers of values and political beliefs but also as moral and political actors in their own right.

4. While not unique to the explanation of social reproduction, sociologists face a tension in their use of terms between, on the one hand, novelty and analytical precision, and on the other hand, transferability within sociological subdisciplines and across sociology. Future work can continue to examine how to make "socialization" work as a productive theory useful both for sociologists and broader publics. 
Whatever Happened to Socialization? (Forthcoming in Annual Review of Sociology)

By Jeffrey Guhin, Jessica Calarco, and Cynthia Miller-Idriss

\section{References}

Alexander JC. 1978. Formal and Substantive Voluntarism in the Work of Talcott Parsons: A Theoretical and Ideological Reinterpretation. American Sociological Review 43(2):177-198

Alexander JC. 1995. Fin de siècle social theory: Relativism, reduction, and the problem of reason. New York: Verso.

Allen, Q. 2016. 'Tell your own story': manhood, masculinity and racial socialization among black fathers and their sons. Ethnic and Racial Studies 39(10):1831-1848

Althusser L 1971. Lenin and Philosophy and Other Essays. Tr. Ben Brewster. London: New Left Books

Archer MS. 1995. Realist Social Theory: The Morphogenetic Approach. New York: Cambridge University Press.

Banks PA. 2012. Cultural socialization in black middle-class families. Cultural Sociology 6(1): 61-73

Besbris M \& and Khan S. 2017. Less Theory. More Description. Sociological Theory 35(2):147-153

Beier H. 2016. How do "Subcultures of Violence" lead to violence? The interplay of internalization and prevalence of norms legitimizing violence in the explanation of youth violence." Kölner Zeitschrift für Soziologie und Sozialpsychologie 68:457-485

Berger PL \& Luckmann T. 1967. The social construction of reality: A treatise in the sociology of knowledge. New York: Anchor Books

Bernstein B. 2003. Class, codes and control Volume II: Applied studies towards a sociology of language. New York: Routledge.

Bonilla-Silva, E, Goar C, \& Embrick DG. When whites flock together: The social psychology of white habitus. Critical Sociology 32(2-3):229-253

Bonilla-Silva E. 2003. Racial attitudes or racial ideology? An alternative paradigm for examining actors' racial views. Journal of Political Ideologies 8(1):63-82

Bourdieu P \& Passeron JC. 1977 [1970]. Reproduction in Education, Society and Culture. Tr. Richard Nice. London: Sage

Bourdieu P 1977 [1972]. Outline of a Theory of Practice. Tr. Richard Nice. New York: Cambridge University Press

Bourdieu P. 1984 [1979]. Distinction: A social critique of the judgement of taste. Tr. Richard Nice. Cambridge, MA: Harvard University Press

Bos AL, Holman MR, Greenlee JS, Oxley ZM \& Lay, JC. 2020. 100 Years of Suffrage and Girls Still Struggle to Find Their 'Fit' in Politics. PS: Political Science \& Politics 53(3):474-78

Bowles S \& Gintis H. 1976. Schooling in capitalist America: Educational reform and the contradictions of economic life. New York: Routledge \& Kegan Paul

Brown P \& Gaskins S. 2014. Language acquisition and language socialization. Cambridge Handbook of Linguistic Anthropology. Ed. Enfield, NJ, Kockelman P \& Sidnell J. New York: Cambridge University Press pp 187-226

Burt CH, Simons RL \& Gibbons FX. 2012. Racial discrimination, ethnic-racial socialization, and crime: A micro-sociological model of risk and resilience. American Sociological Review 77(4):648-677 Butler J. 1990. Gender trouble: Feminism and the subversion of identity. New York: Routledge Butler-Barnes, ST, Martin PP \& Boyd DT. 2017 African American Adolescents' Psychological Well- 
Whatever Happened to Socialization? (Forthcoming in Annual Review of Sociology)

By Jeffrey Guhin, Jessica Calarco, and Cynthia Miller-Idriss

Being: The Impact of Parents' Religious Socialization on Adolescents' Religiosity Race and Social Problems 9: 15-126

Camic C. 1986. The matter of habit American Journal of Sociology 91(5):1039-1087

Carter MJ. 2014. Gender socialization and identity theory Social Sciences 3(2):242-263

Carter PL. 2005. Keepin' it real: School success beyond Black and White. New York: Oxford University Press

Calarco JM. 2018. Negotiating opportunities: How the middle class secures advantages in school. New York: Oxford University Press

Cerulo KA. 2010. Mining the intersections of cognitive sociology and neuroscience Poetics 38(2): 115-132

Cohen J, Hazelrigg LE \& Pope W. 1975. De-Parsonizing Weber: A critique of Parsons' interpretation of Weber's sociology American Sociological Review 40(2):229-241

Collins R. 2019. The credential society: An historical sociology of education and stratification. New York: Columbia University Press

Collins R. 1971. Functional and conflict theories of educational stratification American Sociological Review 36(6):1002-1019

Connell RW. 2005. Masculinities. $2^{\text {nd }}$. Ed. Malden, MA: Polity

Corsaro WA. 1992. Interpretive reproduction in children's peer cultures Social Psychology Quarterly 55(2):160-177

Corsaro WA. 2018. The Sociology of Childhood. $5^{\text {th }}$ ed. Los Angeles: Sage

Corsaro, WA \& Rizzo TA. 1988. Discussione and Friendship: Socialization Processes in the Peer Culture of Italian Nursery School Children American Sociological Review 53(6):879-894

Dewey J. 1958 [1922]. Human Nature and Conduct. $2^{\text {nd }}$ Ed. New York: Dover

DiMaggio P. 1997. Culture and cognition Annual Review of Sociology 23(1):263-287

Dow DM. 2016. The deadly challenges of raising African American boys: Navigating the controlling image of the "thug" Gender \& Society 30(2):161-188

Durkheim, E. 1973 [1925]. Moral Education. Tr. EK Wilson \& H Schnurer. New York: Free Press.

Elder Jr, GH. 1994. Time, human agency, and social change: Perspectives on the life course Social Psychology Quarterly 57(1)4-15

Emirbayer, M \& Mische A. 1998. What is agency? American Journal of Sociology 103(4): 962-1023

Everitt JG \& Tefft T. 2019. Professional socialization as embedded elaborations: Experience, institutions, and professional culture throughout teacher careers Symbolic Interaction 42(4):564587.

Feagin JR \& Van Ausdale D. 2001. The first R: How children learn race and racism. Lanham, MD: Rowman \& Littlefield Publishers.

Foucault, Michel. 1990. Tr. Robert Hurley. The History of Sexuality, Volume 1. New York: Vintage.

Fox JE \& Miller-Idriss C. 2008. Everyday nationhood Ethnicities 8(4):536-563

Gaddis, SM. 2013. The influence of habitus in the relationship between cultural capital and academic achievement. Social Science Research 42(1):1-13

Gans HJ. 2011. The Moynihan report and its aftermaths: A critical analysis. Du Bois Review: Social Science Research on Race 8(2):315-327

Gansen HM. 2017. Reproducing (and disrupting) heteronormativity: Gendered sexual socialization 
Whatever Happened to Socialization? (Forthcoming in Annual Review of Sociology)

By Jeffrey Guhin, Jessica Calarco, and Cynthia Miller-Idriss

in preschool classrooms Sociology of Education 90(3):255-272

Garner B \& Grazian D. 2016. Naturalizing Gender through Childhood Socialization Messages in a Zoo. Social Psychology Quarterly 79(3):181-198

Garfinkel H. 1967. Studies in Ethnomethodology. Malden, MA: Prentice Hall.

Giddens A. 1984. The Constitution of Society: Outline of the Theory of Structuration. Berkeley, CA: University of California Press.

Giddens A. 1968. Power in the recent writings of Talcott Parsons Sociology 2(3):257-272.

Giddings F. 1897. The Theory of Socialization: A Syllabus of Sociological Principles. New York: MacMillan

Goodwin C. 2018. Co-operative action. New York: Cambridge University Press

Goffman E. 1959. The presentation of self in everyday life. New York: Doubleday

Goffman E. 1961. Asylums. New York: Anchor Books

Golash-Boza T. 2016. A critical and comprehensive sociological theory of race and racism Sociology of Race and Ethnicity 2(2):129-141

Goldstein A. \& Kadlubov D. 1998. Gangs in Schools: Signs, Symbols and Solutions. Champaign, Illinois: Research Press.

Gonzalez SM. 2019. Making It Home: An Intersectional Analysis of the Police Talk Gender \& Society 33(1): 363-386.

Gorski PS. 2016. Just how Pascalian are the Pascalian Meditations? Critical reflections on the theological unconscious of Bourdieusian theory. Sociology of Religion 77(3):280-296

Griswold W. 1987. A methodological framework for the sociology of culture. Sociological Methodology (17):1-35.

Gross N. 2018. Pragmatism and the study of large-scale social phenomena. Theory and Society 47(1): 87-111.

Hagerman, MA. 2014. White families and race: Colour-blind and colour-conscious approaches to white racial socialization. Ethnic and Racial Studies 37(14): 2598-2614.

Hall S. 2019. Essential Essays Vol. 1. Foundations of Cultural Studies. Ed. Morley D. Durham: Duke University Press.

Harvey DL \& Reed MH. 1996. The culture of poverty: An ideological analysis. Sociological Perspectives 39(4): 465-495

Hitlin S \& Piliavin JA. 2004. Values: Reviving a dormant concept Annual Review of Sociology 30:359393

Hitlin S. 2011. Values, personal identity, and the moral self. Handbook of identity theory and research, Vol. 1. Ed. Schwartz SA, Luyckx K, \& Vignoles VL. New York: Springer, pp. 515-529.

Hordge-Freeman E. 2015. The color of love: Racial features, stigma, and socialization in black Brazilian families Austin: University of Texas Press

Horne C \& Mollborn S. 2020. "Norms” Annual Review of Sociology 2020 46:467-487.

Hughes D, Rodriguez J, Smith EP, Johnson DJ, Stevenson HC \& Spicer P. Parents' ethnic-racial socialization practices: a review of research and directions for future study. 2006 Developmental Psychology 42(5):747-770.

Jansen RS. 2017. Revolutionizing Repertoires: The Rise of Populist Mobilization in Peru. Chicago: University of Chicago Press

Joas, H. 2000. Tr. G Moore. The Genesis of Values. Tr. Chicago: University of Chicago Press. 
Whatever Happened to Socialization? (Forthcoming in Annual Review of Sociology)

By Jeffrey Guhin, Jessica Calarco, and Cynthia Miller-Idriss

Jost JT. 2006. The end of the end of ideology. American psychologist 61(7):651-670

Landolt P \& Goldring L. 2009. Immigrant political socialization as bridging and boundary work: Mapping the multi-layered incorporation of Latin American immigrants in Toronto Ethnic and racial studies 32(7): 1226-1247.

Lareau A. 2003. Unequal childhoods: Class, race, and family life. Berkeley, CA: University of California Press

Levy G \& Sasson-Levy O. 2008. Militarized socialization, military service, and class reproduction: The experiences of Israeli soldiers Sociological Perspectives 51(2):349-374

Lewis AE \& Diamond JB. 2015. Despite the best intentions: How racial inequality thrives in good schools. New York: Oxford University Press

Lewis O. 1959. Five families: Mexican case studies in the culture of poverty. New York: Basic Books.

Lewis-McCoy, RL. 2014. Inequality in the promised land: Race, resources, and suburban schooling. Stanford: Stanford University Press

Lizardo O. 2018. Culture, Cognition, and 'Socialization.' Blog Post. Culturecog. https://culturecog.blog/2018/07/26/culture-cognition-and-socialization/

Lizardo O. 2017. Improving cultural analysis: Considering personal culture in its declarative and nondeclarative modes. American Sociological Review 82(1):88-115

Lizardo O. 2009. Is a "special psychology" of practice possible? From values and attitudes to embodied dispositions. Theory \& Psychology 19(6):713-727

Lizardo O \& Strand M. 2010. Skills, toolkits, contexts and institutions: Clarifying the relationship between different approaches to cognition in cultural sociology Poetics 38.2: 205-228

Lizardo O, Mowry R, Sepulvado B, Stoltz DS, Taylor MA, Van Ness J, \& Wood M. 2016. What are dual process models? Implications for cultural analysis in sociology Sociological Theory 34(4):287-310

Luft A. 2015. Toward a dynamic theory of action at the micro level of genocide: Killing, desistance, and saving in 1994 Rwanda. Sociological Theory 33(2):148-172

Luhmann, Niklas. 1995. Social Systems. Stanford: Stanford university Press

Martin, JL \& Lembo A. 2020. On the Other Side of Values. American Journal of Sociology. 126(1): 52-98

Manne K. 2017. Down girl: The logic of misogyny. New York: Oxford University Press

McFarland DA \& Thomas RJ. 2006. Bowling young: How youth voluntary associations influence adult political participation American Sociological Review 71(3): 401-425.

Mehta J \& Davies S. Eds. 2018. Education in a new society: renewing the sociology of education. Chicago: University of Chicago Press

Miettinen R, Paavola S \& Pohjola P. 2012. From habituality to change: Contribution of activity theory and pragmatism to practice theories Journal for the Theory of Social Behaviour 42(3):345360.

Miles A. 2015. The (re) genesis of values: Examining the importance of values for action American Sociological Review 80(4):680-704.

Mills CW. 1940. Situated actions and vocabularies of motive American sociological review 5(6):904-913. Milner M. 2013. Freaks, geeks, and cool kids. New York: Routledge 
Whatever Happened to Socialization? (Forthcoming in Annual Review of Sociology)

By Jeffrey Guhin, Jessica Calarco, and Cynthia Miller-Idriss

Moynihan DP. 1965. The Negro family: The case for national action. US Government Printing Office.

Muggleton D. 2000. Inside Subculture: The Postmodern Meaning of Style. New York: Berg

Nash R. 2003. Social explanation and socialization: on Bourdieu and the structure, disposition, practice scheme. The sociological review 51(1):43-62

Niemi RG \& Hepburn MA. 1995. The rebirth of political socialization. Perspectives on Political Science 24(1):7-16

Nunnally SC. 2012. Trust in Black America: Race, discrimination, and politics. New York: New York University Press.

Ochs E. 1999. Socialization Journal of Linguistic Anthropology 9(1/2):230-233

Parsons T. 1952. Superego and the Theory of Social Systems Psychiatry 15(1):15-25

Parsons T. 1951. The Social System. New York: The Free Press.

Pascoe CJ. 2013. Notes on a sociology of bullying: Young men's homophobia as gender socialization. QED: A Journal in GLBTQ Worldmaking. Fall:87-104.

Piaget J. 1965 [1932]. The Moral Judgement of the Child. New York: Free Press.

Powell WM \& DiMaggio PJ, eds. 1991. The New Institutionalism in Organizational Analysis. Chicago: University of Chicago press.

Pugh AJ. 2009. Longing and belonging: Parents, children, and consumer culture. Berkeley, CA: University of California Press.

Pugh AJ 2014. The theoretical costs of ignoring childhood: Rethinking independence, insecurity, and inequality. Theory and Society 43(1):71-89

Rawls AW. 2011. Garfinkel, ethnomethodology and the defining questions of pragmatism. Qualitative Sociology 34(1): 277-282

Rawls AW \& Turowetz J. 2019. "Discovering culture" in interaction: solving problems in cultural sociology by recovering the interactional side of Parsons' conception of culture. American Journal of Cultural Sociology 1-28

Risman BJ \& Davis G. 2013. From Sex Roles to Gender Structure Current Sociology 61(5-6): 733-755.

Röder A. 2015. Immigrants' Attitudes toward Homosexuality: Socialization) Religion, and Acculturation in European Host Societies International Migration Review 49(4):1042-1070.

Romero M. 2017. Introducing intersectionality. Medford, MA: Polity Press

Said E. 1979. Orientalism. New York: Vintage

Sallaz, JJ. 2010. Talking race, marketing culture: The racial habitus in and out of apartheid Social Problems 57(2)294-314.

Sapiro V. 2004. Not your parents' political socialization: Introduction for a New Generation. 2004. Annual Review of Political Science 7:1-23.

Schneiderhan E. 2011. Pragmatism and empirical sociology: the case of Jane Addams and HullHouse, 1889-1895. Theory and Society 40(6):589-617

Schwartz, SH. 2010. Basic Values: How They Motivate and Inhibit Prosocial Behavior Prosocial Motives, Emotions, and Behavior, ed. by Mikulincer M \& Shaver PR. Washington, DC: American Psychological Association, pp. 221-242.

Seamster L. 2015 The white city: Race and urban politics Sociology Compass 9(12):1049-1065.

Sewell WH. 1992. A Theory of Structure: Duality, Agency, and Transformation American Journal of Sociology 98(1):1-29. 
Whatever Happened to Socialization? (Forthcoming in Annual Review of Sociology)

By Jeffrey Guhin, Jessica Calarco, and Cynthia Miller-Idriss

Shapiro L. 2019. Embodied cognition. New York: Routledge.

Shedd C. 2015. Unequal city: Race, schools, and perceptions of injustice. New York: Russell Sage Foundation

Simmel G. 1895. The Problem of Sociology The Annals of the American Academy of Political and Social Science 6(3):52-63

Singh-Manoux A \& Marmot M. 2005. Role of socialization in explaining social inequalities in health Social science \&o medicine 60(9):2129-2133

Small ML, Harding DJ \& Lamont M. 2010. Reconsidering culture and poverty. The Annals of the American Academy of Political and Social Science 629(1):6-27.

Stevens, M. 2008. Culture and Education. The Annals of the Amererican Academy of Political and Social

Science. 619(1):97-113.

Stivers T, Sidnell J \& Bergen C. 2018. Children's responses to questions in peer interaction: A window into the ontogenesis of interactional competence. Journal of Pragmatics 124: 14-30.

Swidler A. 2013. Talk of love: How culture matters. Chicago: University of Chicago Press.

Tavory I. 2010. Of yarmulkes and categories: Delegating boundaries and the phenomenology of interactional expectation. Theory and Society 39(1):49-68

Taylor MA, Stoltz DS \& McDonnell TE. 2019. Binding significance to form: Cultural objects, neural binding, and cultural change. Poetics 73: 1-16.

Thorne B. 1993. Gender play: Girls and boys in school. New Brunswick: Rutgers University Press

Tilly C. 1998. Durable inequality. Berkeley, CA: University of California Press

Toren C. 1999. Mind, materiality, and bistory: explorations in Fijian ethnography. New York: Routledge

Tyson K. 2003. Notes from the back of the room: Problems and paradoxes in the schooling of young black students. Sociology of Education 76(4):326-343.

Vaisey S. 2014. Is interviewing compatible with the dual-process model of culture. American Journal of Cultural Sociology 2(1):150-158.

Vaisey S. 2009. Motivation and justification: A dual-process model of culture in action. American Journal of Sociology 114(6):1675-1715.

Vaisey S \& Valentino L. 2018. Culture and choice: toward integrating cultural sociology with the judgment and decision-making sciences. Poetics 68: 131-143

Vaisey S \& Lizardo O. 2016. Cultural fragmentation or acquired dispositions? A new approach to accounting for patterns of cultural change. Socius

Valencia RR. 2012. Ed. The evolution of deficit thinking: Educational thought and practice. New York: Routledge

Vanderstraeten R. 2000. "Autopoiesis and socialization: on Luhmann's reconceptualization of communication and socialization." The British journal of sociology 51(3):581-598

Wacquant LJD. 2004. Body \& soul. New York: Oxford University Press

Waters MC \& Jiménez TR. 2005. Assessing immigrant assimilation: New empirical and theoretical challenges. Annual Review of Sociology 31: 105-125.

West C \& Zimmerman DH. 1987. Doing gender. Gender \& society 1(2): 125-151.

Willis P. 1981. Learning to Labor: How Working-Class Kids get Working-Class Jobs. New York: Columbia University Press.

Wilson WJ. 2009. The Moynihan Report and research on the black community. The Annals of the 
Whatever Happened to Socialization? (Forthcoming in Annual Review of Sociology)

By Jeffrey Guhin, Jessica Calarco, and Cynthia Miller-Idriss

American Academy of Political and Social Science 621(1): 34-46.

Wilson WJ. 2010. Why both social structure and culture matter in a holistic analysis of inner-city poverty. The Annals of the American Academy of Political and Social Science 629(1):200-219

Winchester D \& Guhin J. 2019. Praying "Straight from the Heart": Evangelical sincerity and the normative frames of culture in action. Poetics (72):32-42.

Winchester D \& Green KD. 2019. Talking your self into it: How and when accounts shape motivation for action. Sociological Theory 37(3):257-281

Winchester D. 2016. A hunger for God: Embodied metaphor as cultural cognition in action Social Forces 95(2): 585-606.

Wrong, DH. 1976. Skeptical sociology. New York: Columbia University Press.

Zerubavel E. 2009. Social mindscapes: An invitation to cognitive sociology. Cambridge, MA: Harvard University Press. 


\section{Appendix: Methods for Journal "Socialization" Use}

First, a set of 18 journals were selected for data collection. Four of these journals were omitted because of a lack of returned results from the search procedure employed. ${ }^{3}$ The remaining journals returned a low threshold of more than 10 articles, and are listed in Table A1.

To develop the list of articles, Web of Science (WoS) Core Collection was searched on June $20^{\text {th }}$, 2020. A TOPIC search was chosen as it covers abstracts, titles, keywords, and the WoS "keywords plus" feature. This was done to get a "universe" where one could analyze the larger body of "socializations" usage. All articles from all journals were collected. WoS searches start in 1900, and thus cover the entire life of each journal, except for AJS, which started in 1985. WoS was preferred initially because of its encompassing, but not over encompassing, search options and the ability to download 500 references at a time.

TOPIC: (socializ* or socialisation) Refined by: DOCUMENT TYPES: (ARTICLE) AND LANGUAGES: (ENGLISH) Timespan: All years, Indexes: SCI-EXPANDED, SSCI, A\&HCI, CPCI-S, CPCI-SSH, BKCI-S, BKCI-SSH, ESCI, CCR-EXPANDED, IC.

Due to sub-ideal coverage by WoS for the journals of interest, Jstor was used to supplement the resulting articles for the particular journals of interest. Jstor was searched with the search term (socializ*) OR socialisation for both the titles and the abstracts for each of the specifically analyzed journals. ${ }^{4}$ All fields was not used as it tests and communication with Jstor staff indicated that this term conducts a fulltext search, while caption was also not used. Book reviews returned as articles were omitted. The disadvantage was the search did not target subject listings, and only allowed 50 references to be exported at a time.

Duplicates returned by both search engines were removed. Only articles published in 2019 or earlier were considered when making the graphs. Table 1A below presents information about the number of "hits" regarding socialization for each journal, and the first year the term appears.

Table A1: Article Return Frequency through 2019

\begin{tabular}{lrrrrr} 
Journal & Instances & \multicolumn{2}{c}{ First Usage } \\
American Journal of Sociology (AJS) & 97 & & 1912 & \\
American Sociological Review (ASR) & 96 & & 1941 & \\
Social Forces (SF) & 99 & & 1923 & \\
American Political Science Review (APSR) & 34 & & 1967 & \\
Social Psychology Quarterly (SPQ) & 43 & & 1979 & \\
Social Problems (SP) & 34 & & 1959 & \\
Journal of Scientific Study of Religion (JSSR) & 69 & & 1964 \\
International Migration Review (IMR) & & 12 & & 1986 \\
Journal of Health and Social Behavior (JHSB) & 60 & & 1967 & \\
Sociology of Education (SoE) & & 71 & & 1960 \\
Administrative Science Quarterly (ASQ ) & 35 & & 1960 & \\
Ethnic and Racial Studies (ERS) & & 28 & & 1996 \\
Gender \& Society (GS) & \multicolumn{2}{c}{19} & & 1987 \\
Psychological Bulletin (PB) & 13 & & 1973 &
\end{tabular}

\footnotetext{
${ }^{3}$ The journals dropped were Sociological Theory (2), American Education Review (0) Journal, Demography (8), and Journal of Development Economics (0).

${ }^{4}$ For example: (((ti:(socializ*) OR ab:(socializ*)) OR ti:(socialisation)) OR ab:(socialisation)) AND pt:(Journal for the Scientific Study of Religion)
} 
The search results were taken at face value and counted because they were returned. A problem arises where "socialize" is used in the sense of meeting with another person, rather than "socialize" as the act of socializing. However, (socialis*) was not used given the significant false positives that would result from socialism and its derivatives. Additionally, returns are subject to peculiarities in the coding of journals and the search providers. For example, Social Forces returns a larger number of hits after 2010 that do not have "socailiz"" in the title or abstract than the American Journal of Sociology or the American Sociological Review. However, Social Forces still returns more than those journals subtracting these non-title, non-abstract article.

Table A1 and A2 present the five-year moving averages for the journals not displayed in the main text.

\section{A1: Five-Year Moving Average by Journal for "Socialization"}

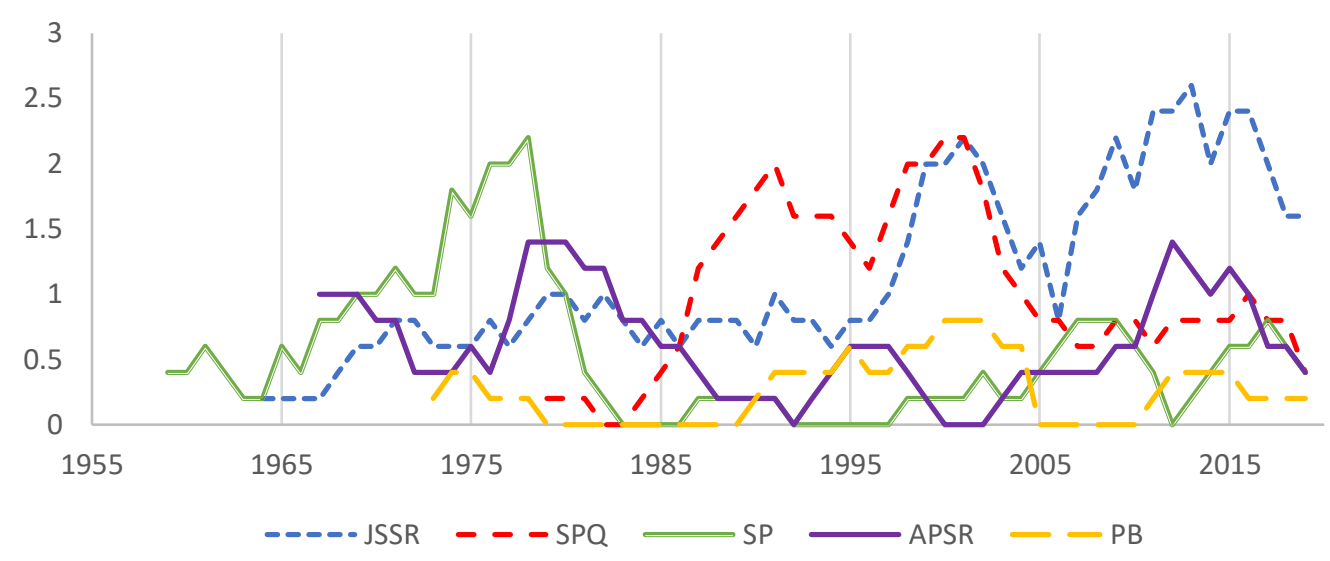

\section{A2: Five-Year Moving Average by Journal for} "Socialization"

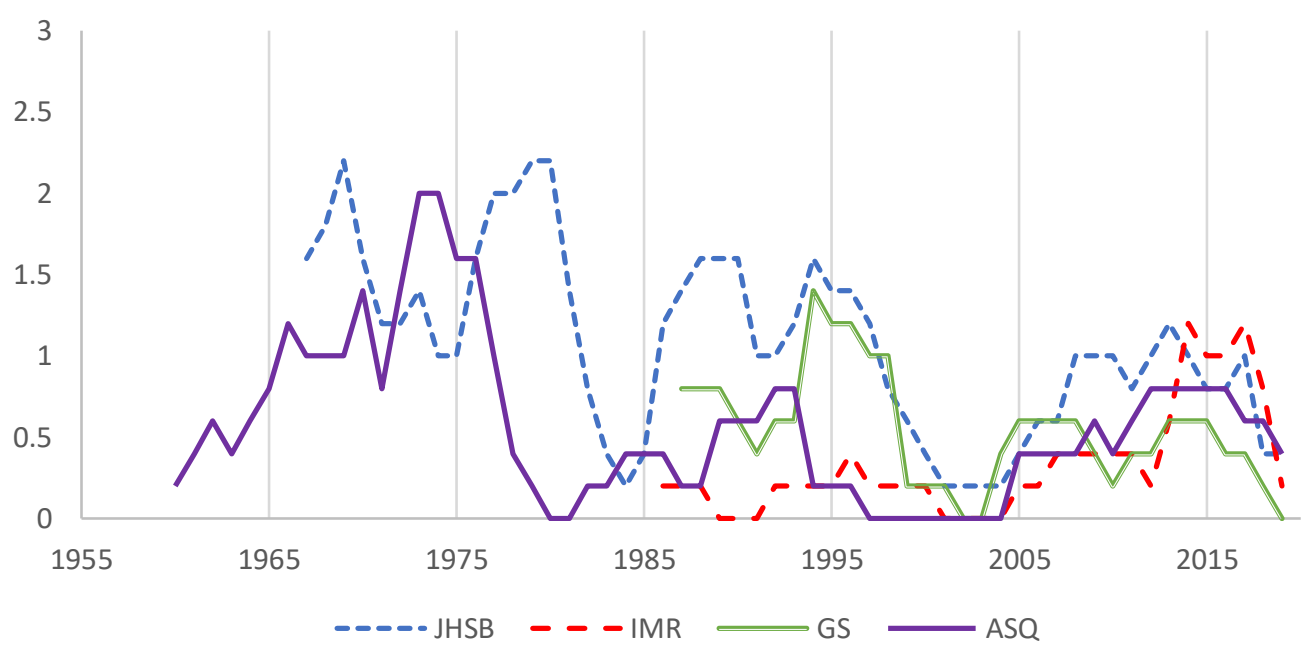

Database coverage may have particularistic problems for a given journal, and such problems were taken as is. For example, the American Journal of Sociology does not have abstracts prior to the 1920s, 
Whatever Happened to Socialization? (Forthcoming in Annual Review of Sociology)

By Jeffrey Guhin, Jessica Calarco, and Cynthia Miller-Idriss

Social Forces does not have abstracts in the 1920s and parts of the 1950s. These coverage concerns should be kept in mind, but do not directly relate to the contemporary interests of the paper. Also, the allocation of key terms or subject indicators is not ideal, as even Becker's (1953) American Journal of Sociology classic "Becoming a Marihuana User" does not appear in the data as "socializ"" is not in the abstract or title. As such, the search term used is a sampling strategy thought to capture general movements, rather than useful for creating a satisfactory universe of articles about socialization. 